\title{
Effects of Pre-sowing Treatments on Seed Germination of Oaks in Kumaun, West Himalaya
}

\author{
Meenakshi NEGI*, Ranbeer S. RAWAL \\ G.B. Pant National Institute of Himalayan Environment and Sustainable Development, Kosi-Katarmal, Almora 263 643, Uttarakhand, \\ India; meenakshinegi.293@gmail.com (*correspondingauthor)
}

\begin{abstract}
The noticeable decline in natural regeneration of three important species of West Himalayan oaks, namely Quercus glauca, Q. leucotrichophora and Q. lanuginosa, on account of excessive lopping, over grazing and tree felling accompanied by non-viable seeds due to short viability, extreme weevil and pest infestation, animal and bird predation resulting in low acorn production and thus overall poor natural regeneration, is of great concern. A study was therefore, carried out with an objective to find out possibilities of improving germination ability of selected oak species using different pre-sowing treatments on three seed size classes- small, medium and large collected from Nainital region of Uttarakhand. A wide variation in seed size existed within these species and germination was found to vary with seed weight; large and medium size seeds exhibiting higher germination. Under various pre-sowing treatments, seeds from different species did not reflect uniformity in responses. Among all the set of experiments, water soaking $(48 \mathrm{~h})$ proved to be the best and cost effective approach by significantly improving seed germination over control, Q. glauca (53.3 to 73.3\%), Q. leucotrichophora (66.67 to 90.0\%) and Q. lanuginosa (58.33 to $75.0 \%$ ). However, acid scarification emerges as effective pre-sowing treatment. Both water soaking and acid scarification treatments also helped in reducing Mean Germination Time. The outcomes of this study clearly reflect some of the simple, practical and cost effective methods for mass seedling production and restoration of degraded hills in west Himalaya.
\end{abstract}

Keywords: acorn size; Himalayan oaks; pre-sowing treatments; seed germination; Quercus glauca; Q. leucotrichophora; Q. lanuginosa

\section{Introduction}

Oaks (genus Quercus) form an important group of trees (family Fagaceae) not only in the Indian sub-continent, but also in Europe, North America, Japan, etc, primarily occurring in temperate to sub-temperate climate. There are over 600 oak species distributed across the world, with maximum diversity in Mexico (around 160 species; 109 as endemics) and China (over 100 species) (Oldfield and Eastwood, 2007). In India are over 35 species of oaks are reported (Negi and Naithani, 1995).

In the west Himalaya, 5 species of evergreen oaks, namely Q. leucotrichophora (Banj), Q. glauca (Phaliyant), Q. lanuginosa (Rianj), Q. floribunda (Tilonj/Moru) and Q. semecarpifolia (Kharsu) grow naturally. These species are widely distributed, gregarious in occurrence, and well known for their economic and ecosystem values.

However, poor natural regeneration is of great concern for west Himalayan oaks due to several reasons, like, excessive lopping, over grazing and tree felling, non-viable seeds, extreme weevil and pest infestation, animal and bird predation resulting in low acorn production (Saxena and Singh, 1984; Thadani and Ashton, 1995). Seed germination, seedling performance, natural regeneration and subsequent growth in oaks are often attributed to their recalcitrant nature and wide variation in acorn size within a species (Tripathi and Khan, 1990; Khan and Shankar, 2001; Purohit et al., 2003; Tilki and Alptekin, 2006).

In general, efforts of clonal propagation (Bhardwaj et al., 1996; Tamta et al., 2000) have not much succeeded in most oak species in the region. Therefore, improvement of natural regeneration and mass propagation using seeds seems to be most viable alternative.

The present study, therefore, is an attempt to improve seed germination, using various pre-treatments, in three oak species (i.e., Q. leucotrichophora, Q. glauca and Q. lanuginosa) of the region. The study intends to identify best responding treatments so as to promote the large scale production of planting material for these highly preferred species in west Himalaya. 


\section{Materials and Methods}

\section{Seed collection}

Mature seeds (acorns) of all three target species were collected from different forest sites near Nainital (Kumaun forest division, Uttarakhand). Following the seed maturation, seeds of $Q$. glauca were collected in the month of October/November, Q. leucotrichophora in November/December and $Q$. lanuginosa in December/January (year 2014-2015). Geo-coordinates and altitude of each site was recorded using hand held Global Positioning System [GPS (Garmin make)]. Seeds after measuring fresh weight were stored in a paper bag at temperature $\left(25 \pm 2^{\circ} \mathrm{C}\right)$ until the experimentation.

\section{Morphological analysis}

A total of 30 seeds $(10$ seeds $\times 3$ sets $=30)$ per species were randomly selected and various morphological attributes like acorn length, acorn width and acorn fresh weight were recorded. Acorn length and width were measured using digital Vernier's calliper (Mitutoya, Japan) and fresh weight using weighting balance (Citizen Scale CY 510).

\section{Determination of weight classes}

Randomly selected 100 seeds for each of the target species were weighted for the fresh weight. Considering minimum and maximum fresh weight values, ranging from $1.18 \mathrm{~g}$ to $2.42 \mathrm{~g}$ for $Q$. glauca, $1.15 \mathrm{~g}$ to $2.61 \mathrm{~g}$ for $Q$. leucotrichophora and $0.89 \mathrm{~g}$ to $1.95 \mathrm{~g}$ for $Q$. lanuginose, three size classes (small, medium and large) were made (Table 1).

\section{Determination of moisture content}

Seed moisture content was determined using ten seeds for each of the three replicates. After taking fresh weight, seeds were oven dried at $60{ }^{\circ} \mathrm{C}$ for $48 \mathrm{~h}$. The oven dried seeds were reweighted and the moisture content was calculated as: Moisture $(\%)=\mathrm{FW}-\mathrm{DW} \times 100 / \mathrm{FW}$, where FW is Fresh weight $(\mathrm{g})$ and DW is weight after oven drying (g).

\section{Viability test}

Viability of seeds across weight classes of each species was assessed following the standard approach (Hendry and Grime, 1993). Thirty seeds (three replicates, each with ten seeds) from each weight class were immersed in a $1 \%$ aqueous solution of 1,2 , and 3- triphenyl tetrazolium chloride (pH- 6.0) for $24 \mathrm{~h}$ in dark $\left(25 \pm 2^{\circ} \mathrm{C}\right)$. Percent viability was determined by calculating the number of stained embryos in each weight class.
Seed size and germination responses

Germination across weight classes of untreated seeds (three sets of 10 seeds each) was performed on selected oak species. This germination test on untreated seeds served as control for respective weight class of given species. Seeds were placed in Petri plates $(95 \times 17 \mathrm{~mm})$ containing moistened filter paper (Whatmann No. 1). Petri plates were kept in growth chamber at a constant temperature $\left(25 \pm 2^{\circ} \mathrm{C}\right)$. Seeds were considered germinated when the tip of the radical emerged $(2 \mathrm{~mm})$ from the seed. Thereafter, weekly observations were recorded. Mean Germination Time (MGT) was calculated as: MGT $=\sum(\mathrm{n} \times \mathrm{d}) / \mathrm{N}$; where $\mathrm{n}=$ the number of seeds which germinated after each period of incubation in days $\mathrm{d}$ and $\mathrm{N}=$ the total number of seeds emerged at the end of the test (Hartmann and Kester, 1989).

\section{Pre-sowing treatments and germination responses}

Based on the preliminary results it was noticed that medium and large size seeds in all three species germinate more with lesser Mean Germination Time. Therefore, presowing treatments were applied on pooled seed lots of medium and large weight class. Seeds were pre-treated with Bavistin (0.05\%) solution for 30 minutes, washed 3-4 times thoroughly with distilled water and placed in beakers containing $100 \mathrm{ml}$ of various test solutions for 48 hours. The following tests were conducted for detailed investigation.

\section{Water soaking treatment}

Seeds were soaked in distilled water (12, 24, 36 and 48 hours); water changed after every $12 \mathrm{~h}$ (Hartmann and Kester, 1989). The soaked seeds were incubated on Petriplates and observations were recorded. Treated seeds were subsequently subjected to germination test.

\section{Acidscarification}

Acid scarification was performed by placing seeds in beakers containing sulphuric acid (conc. $\mathrm{H}_{2} \mathrm{SO}_{4}$ ) for 5,10 and $20 \mathrm{~min}$ and occasionally shaken. Immediately after treatment, seeds were washed 3-4 times vigorously under tap water. Treated seeds were allowed to imbibe for 48 hours in distilled water before incubating on Petri-plates for germination.

\section{Plant Growth Regulators (PGRs) and chemical treatments}

Seeds were soaked for 48 hours to examine the effect of different concentration of plant growth regulators [Gibberellic acid $\left(\mathrm{GA}_{3)}\right.$ and Indole-3- acetic acid (IAA)]; $100,200$ and $400 \mu \mathrm{M})$ and nitrogenous compounds (Thiourea and $\mathrm{KNO}_{3} ; 50 \mathrm{mM}$ and $100 \mathrm{mM}$ ) on germination.

\begin{tabular}{cccc}
\hline & & Fresh weight $(\mathrm{gm})$ & Large \\
\hline Weight class $\rightarrow$ & Small & Medium & $>2.00$ \\
Species $\downarrow$ & $<1.50$ & $1.50-2.00$ & $>2.00$ \\
Q. glauca & $<1.50$ & $1.50-2.00$ & $>1.50$ \\
Q. leucotrichophora & $<1.00$ & $1.00-1.50$ & \\
Q. lanuginosa & &
\end{tabular}


284

\section{Statistical analysis}

Data were subjected to analysis of variance (ANOVA) and multivariate analysis using SPSS programme (version 16.0) for comparison of the means of germination percentage on different treatments. The significance level was determined at $p<0.05$ and the means were separated using Duncan's multiple range test (DMRT), if the values were significantly different. Data are presented as mean values \pm standard error $(\mathrm{SE})$.

\section{Results}

Major attributes on seed morphology, moisture content and viability

Variations in all morphological characteristics of acorns in the targeted species were observed and recorded (Table 2). Among the studied oaks, Q. leucotrichophora was found to have maximum seed weight (1.15-2.61 g), seed length $(20.81 \mathrm{~mm})$ and width $(11.66 \mathrm{~mm})$. Seed size was found minimum for $Q$. lanuginosa.

In all the species, moisture content increased with increasing seed size (Q. glauca 15.2-23.3\%; $Q$. leucotrichophora 16.5-28.5\%; Q. lanuginosa 10.3-19.2\%). This increase of moisture content was significant $(\mathrm{p}<0.05)$ in all the species. Similarly, the viability also increased with the size of seeds (Q. glauca 53.3-66.6\%; Q. leucotrichophora 46.7-90.0\%; Q. lanuginosa 43.3-56.7\%). However, the increase was significant $(\mathrm{p}<0.05)$ only in the case of $Q$. leucotrichophora from small to medium and large category seeds.

\section{Effect of seed size on germination responses}

Percentage germination was found to increase with increasing seed size from $46.67 \%$ to $53.33 \%$ for $Q$ glauca, $46.67 \%$ to $70 \%$ for $Q$. leucotrichophora and $43.33 \%$ to $60 \%$ for Q. lanuginosa. With increasing seed size significant $(\mathrm{p}<$ $0.05)$ reduction was noticed in MGT except for $Q$. lanuginosa (Table 3).

\section{Effect of pre-sowing treatments on germination}

Germination responses across different pre-sowing treatments varied significantly (Table 4). Germination responses under different water soaking treatments revealed that the germination increased with increasing soaking duration up to $48 \mathrm{~h}$, which was significant over control ( $\mathrm{p}<$ $0.05)$ in all the species. The highest mean germination (90\%) under $48 \mathrm{~h}$ water soaking treatment for $Q$. leucotrichophora was considerably better than the other two species (Q. glauca-73.31\%; Q. lanuginosa-75\%). This treatment also significantly $(\mathrm{p}<0.05)$ reduced the MGT over control in Q. glauca $(96.88 \mathrm{~d}$ to $78.35 \mathrm{~d})$, Q. leucotrichophora (95.39 d to $69.68 \mathrm{~d}$ ) and Q. lanuginosa (71.63 d to $60.87 \mathrm{~d})$.

As compared to control, sulphuric acid scarification treatments helped improving germination. Germination percentage increased with increase in treatment duration up to $10 \mathrm{~min}$ from $53.33 \%$ (control) to $75 \%$ in Q. glauca and $58.33 \%$ (control) to $78.33 \%$ in Q. lanuginosa. Further increase in time duration in general lowered the mean germination [except in Q. leucotrichophora where further increase in germination (83.33\%) was observed under 20 min treatment]. Acid scarification treatment invariably reduced the MGT and reduction was significant over control in most cases.

Among PGRs, IAA did not prove effective in improving germination in all the studied species. Whereas, seeds soaked in $\mathrm{GA}_{3}$ showed significant increase $(\mathrm{p}<0.05)$ in germination percentage with increasing concentration up to $400 \mu \mathrm{M}$ from $53.33 \%$ (control) to $73.33 \%$ in Q. glauca and $58.33 \%$ (control) to $68.33 \%$ in Q. lanuginosa [except for $Q$. leucotrichophora where the mean germination (81.67\%) was higher for $200 \mu \mathrm{M}$ of $\mathrm{GA}_{3}$ ]. Considering MGT, the increased concentration of $\mathrm{GA}_{3}$ mostly helped in reduction in MGT except for Q. lanuginosa where reduction in MGT was non-significant $(\mathrm{p}>0.05)$.

Table 2. Major seed characteristics of three oak species in Kumaun, West Himalaya

\begin{tabular}{cccc}
\hline Attributes & Quercusglauca & Quercus leucotrichophora & Quercus lanuginosa \\
\hline Seed collection site & Kalona (Nainital) & Maheshkhan (Nainital) & Kilbury (Nainital) \\
Altitude (m asl) & 1,470 & 1,950 & 2,230 \\
Geographical co-ordinates & $\mathrm{N} 24^{\circ} 20^{\circ}$ & $\mathrm{N} 29^{\circ} 24^{\prime}$ & $\mathrm{N} 29^{\circ} 25^{\prime}$ \\
Seed maturation time & $\mathrm{E} 79^{\circ} 27^{\prime}$ & $\mathrm{E} 79^{\circ} 32^{\prime}$ & $\mathrm{E} 79^{\circ} 26^{\prime}$ \\
Seed coat & October - November & December - January & January \\
Mean seed length $(\mathrm{mm})$ & Hard & Hard & Hard \\
Mean seed width $(\mathrm{mm})$ & $19.92 \pm 0.36$ & $20.81 \pm 0.18$ & $9.47 \pm 0.10$ \\
\hline
\end{tabular}

Table 3. Effects of seed size on mean germination and MGT in three oak species in Kumaun, West Himalaya

\begin{tabular}{ccccccc}
\hline \multirow{2}{*}{ Weight class } & QG & QL & QLG & QG & QL & QLG \\
\cline { 2 - 7 } & \multicolumn{3}{c}{ Germination responses (\%) } \\
\hline Small & $46.67 \pm 3.34^{\mathrm{a}}$ & $46.67 \pm 6.67^{\mathrm{a}}$ & $43.33 \pm 8.83^{\mathrm{a}}$ & $111.07 \pm 4.98^{\mathrm{a}}$ & $97.80 \pm 2.48^{\mathrm{ab}}$ & $78.00 \pm 7.98^{\mathrm{a}}$ \\
Medium & $53.33 \pm 3.34^{\mathrm{a}}$ & $63.33 \pm 3.3^{\mathrm{a}}$ & $56.67 \pm 8.83^{\mathrm{a}}$ & $99.63 \pm 2.40^{\mathrm{ab}}$ & $102.27 \pm 5.42^{\mathrm{a}}$ & $75.83 \pm 10.36^{\mathrm{a}}$ \\
Large & $53.33 \pm 3.34^{\mathrm{a}}$ & $70.00 \pm 10.01^{\mathrm{a}}$ & $60.00 \pm 5.78^{\mathrm{a}}$ & $94.14 \pm 4.25^{\mathrm{b}}$ & $88.51 \pm 2.68^{\mathrm{b}}$ & $67.43 \pm 10.11^{\mathrm{a}}$ \\
\hline
\end{tabular}

Values are mean \pm standard error; different super script letters in a column indicate significant variation (p < 0.05) based on Duncan multiple range test (DMRT) (QG $=$ Q. glauca $; \mathrm{QL}=$ Q. leucotrichophora and $\mathrm{QLG}=$ Q. lanuginosa) 
Responses of seeds immersed in nitrogenous compounds were more or less similar to $\mathrm{GA}_{3}$ treated seeds. In case of chemical treatments, $\mathrm{KNO}_{3}(100 \mathrm{mM})$ was found better for improving germination from $66.67 \%$ (control) to $85 \%$ followed by Thiourea $(50 \mathrm{mM})$ to $80 \%$ in $Q$. leucotrichophora than other two species. Compared to control, except for $Q$. lanuginosa, these treatments were also found effective in reducing MGT significantly $(\mathrm{p}<0.05)$.

Table 4. Germination responses and MGT under various pre-sowing treatments in three oak species in Kumaun, West Himalaya

\begin{tabular}{|c|c|c|c|c|c|c|c|}
\hline \multirow{2}{*}{$\begin{array}{c}\text { Pre- } \\
\text { treatment }\end{array}$} & \multirow{2}{*}{ Conc./Duration } & $\mathrm{QG}$ & QL & QLG & $\mathrm{QG}$ & QL & QLG \\
\hline & & \multicolumn{3}{|c|}{ Germination response (\%) } & \multicolumn{3}{|c|}{$\operatorname{MGT}(\mathrm{d})$} \\
\hline Control & - & $53.33 \pm 2.12^{g}$ & $66.67 \pm 4.96^{\mathrm{bc}}$ & $58.33 \pm 4.79^{\text {cdef }}$ & $96.88 \pm 2.51^{\mathrm{ab}}$ & $95.39 \pm 4.11^{\mathrm{a}}$ & $71.63 \pm 6.76^{a}$ \\
\hline \multirow{4}{*}{$\mathrm{GA}_{3}$} & $100 \mu \mathrm{M}$ & $56.67 \pm 2.12^{\text {efg }}$ & $73.33 \pm 8.06^{\mathrm{abc}}$ & $60.00 \pm 2.59^{\text {cdef }}$ & $91.38 \pm 1.74^{\mathrm{bc}}$ & $75.15 \pm 2.83^{\text {cde }}$ & $69.34 \pm 3.65^{\mathrm{a}}$ \\
\hline & $200 \mu \mathrm{M}$ & $60.00 \pm 2.59^{\mathrm{defg}}$ & $81.67 \pm 3.09^{\mathrm{ab}}$ & $65.00 \pm 2.24^{\mathrm{bcd}}$ & $90.89 \pm 2.42^{\mathrm{bc}}$ & $71.06 \pm 2.36^{\mathrm{def}}$ & $69.31 \pm 2.31^{\mathrm{a}}$ \\
\hline & $400 \mu \mathrm{M}$ & $73.33 \pm 3.35^{\mathrm{ab}}$ & $65.00 \pm 7.67^{b c}$ & $68.33 \pm 4.03^{\mathrm{abc}}$ & $76.22 \pm 1.51^{\mathrm{gh}}$ & $66.90 \pm 2.66^{\mathrm{efg}}$ & $68.67 \pm 1.61^{a}$ \\
\hline & $100 \mu \mathrm{M}$ & $53.33 \pm 4.23^{\mathrm{g}}$ & $68.33 \pm 6.03^{b c}$ & $50.00 \pm 4.49^{f}$ & $100.04 \pm 2.62^{\mathrm{a}}$ & $91.80 \pm 2.67^{a}$ & $70.27 \pm 3.41^{\mathrm{a}}$ \\
\hline \multirow[t]{2}{*}{ IAA } & $200 \mu \mathrm{M}$ & $55.00 \pm 2.24^{\mathrm{fg}}$ & $60.00 \pm 6.86^{c}$ & $51.67 \pm 4.03^{\mathrm{ef}}$ & $97.84 \pm 2.08^{\mathrm{a}}$ & $81.91 \pm 1.70^{\mathrm{bc}}$ & $70.42 \pm 2.66^{a}$ \\
\hline & $400 \mu \mathrm{M}$ & $56.67 \pm 2.12^{\mathrm{efg}}$ & $65.00 \pm 6.22^{b c}$ & $53.33 \pm 4.23^{\text {def }}$ & $96.18 \pm 2.26^{\mathrm{ab}}$ & $88.27 \pm 4.85^{\mathrm{ab}}$ & $69.99 \pm 3.33^{\mathrm{a}}$ \\
\hline \multirow[t]{2}{*}{$\mathrm{KNO}_{3}$} & $50 \mathrm{mM}$ & $63.33 \pm 3.35^{\text {bcdefg }}$ & $73.33 \pm 4.23^{\mathrm{abc}}$ & $75.00 \pm 4.30^{\mathrm{ab}}$ & $85.13 \pm 1.61^{\text {cde }}$ & $64.47 \pm 2.37^{\mathrm{fgh}}$ & $66.51 \pm 2.22^{\mathrm{ab}}$ \\
\hline & $100 \mathrm{mM}$ & $58.33 \pm 3.09^{\mathrm{efg}}$ & $85.00 \pm 4.30^{\mathrm{ab}}$ & $66.67 \pm 2.12^{\mathrm{abc}}$ & $83.67 \pm 1.26^{\mathrm{def}}$ & $69.50 \pm 2.29^{\mathrm{defg}}$ & $64.55 \pm 2.46^{\mathrm{abc}}$ \\
\hline \multirow{2}{*}{ Thiourea } & $50 \mathrm{mM}$ & $63.33 \pm 2.12^{\text {bcdefg }}$ & $80.00 \pm 5.18^{\mathrm{abc}}$ & $58.33 \pm 4.79^{\text {cdef }}$ & $82.62 \pm 1.87^{\mathrm{ef}}$ & $62.13 \pm 1.42^{\mathrm{fgh}}$ & $66.27 \pm 1.91^{\mathrm{ab}}$ \\
\hline & $100 \mathrm{mM}$ & $70.00 \pm 3.67^{\mathrm{abcd}}$ & $73.33 \pm 8.85^{\mathrm{abc}}$ & $60.00 \pm 3.67^{\text {cdef }}$ & $77.75 \pm 1.50^{\mathrm{fgh}}$ & $62.98 \pm 4.12^{\mathrm{fgh}}$ & $66.71 \pm 4.10^{\mathrm{ab}}$ \\
\hline \multirow{4}{*}{$\begin{array}{l}\text { Water } \\
\text { soaking }\end{array}$} & $12 \mathrm{~h}$ & $61.67 \pm 3.09^{\text {cdefg }}$ & $68.33 \pm 7.95^{b c}$ & $63.33 \pm 4.23^{\mathrm{bcde}}$ & $99.87 \pm 2.06^{\mathrm{a}}$ & $76.69 \pm 2.11^{\mathrm{cd}}$ & $66.09 \pm 2.64^{\mathrm{ab}}$ \\
\hline & $24 \mathrm{~h}$ & $65.00 \pm 2.24^{\mathrm{abcdef}}$ & $80.00 \pm 3.67^{\mathrm{abc}}$ & $65.00 \pm 4.30^{\mathrm{bcd}}$ & $89.82 \pm 2.39^{\mathrm{cd}}$ & $67.68 \pm 3.20^{\mathrm{efg}}$ & $66.12 \pm 2.66^{\mathrm{ab}}$ \\
\hline & $36 \mathrm{~h}$ & $66.67 \pm 3.35^{\mathrm{abcde}}$ & $85.00 \pm 3.43^{\mathrm{ab}}$ & $66.67 \pm 4.23^{\mathrm{abc}}$ & $85.27 \pm 2.11^{\text {cde }}$ & $68.43 \pm 1.55^{\operatorname{defg}}$ & $65.04 \pm 3.81^{\mathrm{abc}}$ \\
\hline & $48 \mathrm{~h}$ & $73.33 \pm 3.35^{\mathrm{ab}}$ & $90.00 \pm 4.49^{\mathrm{a}}$ & $75.00 \pm 4.30^{\mathrm{ab}}$ & $78.35 \pm 2.68^{\mathrm{fgh}}$ & $69.68 \pm 3.34^{\text {defg }}$ & $60.87 \pm 3.19^{\mathrm{abc}}$ \\
\hline \multirow{3}{*}{$\begin{array}{c}\text { Acid } \\
\text { scarification }\end{array}$} & $5 \mathrm{~min}$ & $71.67 \pm 3.09^{a b c}$ & $78.33 \pm 6.03^{\mathrm{abc}}$ & $75.00 \pm 4.30^{\mathrm{ab}}$ & $82.33 \pm 2.14^{\text {efg }}$ & $61.97 \pm 1.72^{\mathrm{fgh}}$ & $57.87 \pm 0.63^{b c}$ \\
\hline & $10 \mathrm{~min}$ & $75.00 \pm 3.43^{\mathrm{a}}$ & $75.00 \pm 6.22^{\mathrm{abc}}$ & $78.33 \pm 3.09^{\mathrm{a}}$ & $73.76 \pm 1.63^{\mathrm{h}}$ & $60.53 \pm 2.42^{\mathrm{gh}}$ & $55.58 \pm 2.54^{\mathrm{c}}$ \\
\hline & $20 \mathrm{~min}$ & $53.33 \pm 5.60^{\mathrm{g}}$ & $83.33 \pm 5.60^{\mathrm{ab}}$ & $56.67 \pm 4.23^{\text {cdef }}$ & $87.61 \pm 1.38^{\text {cde }}$ & $57.43 \pm 1.03^{\mathrm{h}}$ & $64.63 \pm 2.00^{\mathrm{abc}}$ \\
\hline
\end{tabular}

Values are mean \pm standard error; different super script letters in a column indicate significant variation $(\mathrm{p}<0.05)$ based on Duncan multiple range test (DMRT) $(\mathrm{QG}=$ Q.glauca; $\mathrm{QL}=$ Q. leucotrichophora and $\mathrm{QLG}=$ Q. lanuginosa)

\section{Discussion}

The study provides useful understanding on possible improvement of germination responses in targeted three Himalayan oak species. The improved seed germination and decreased MGT with increasing seed weight is in general in agreement with earlier reports for some other oaks, which have often attributed these responses to high energy and nutrient reserves of larger seeds (Tripathi and Khan, 1990; Bonfil, 1998; Bhuyan et al., 2000; Khan and Shankar, 2001).

Positive response of seeds of selected oak species for water soaking supports the findings of Purohit et al. (2009), which reports $48 \mathrm{~h}$ of water soaking duration as most effective for achieving highest germination in Q. glauca and Q. leucotrichophora. The better response with increasing soaking duration suggests that the oak seeds require an optimal level of moisture to activate the embryo to commence the process of cell division, differentiation and multiplication to grow into a seedling. Water soaking has also been found effective for seeds of Q. laurifolia (Larsen, 1963 ) and other important wild tree species in the region, for example Cornus capitata (Airi et al., 2005) and Myrica esculenta (Bhatt et al., 2000).

Improved germination under acid scarification can be attributed to the fact that sulphuric acid breaks physical (seed coat) dormancy by corroding the outermost layers of the seed coat, improving seed permeability and thereby enhance germination (Ren and Tao, 2004; Murat et al., 2010). The present study, therefore, supports that acid scarification is simple and easy to apply on a large lot of seeds over other tedious, labour intensive and time consuming methods of breaking physical dormancy.

Gibberellic acid was found to enhance germination percentage with reduction in MGT in the present study. $\mathrm{GA}_{3}$ is known to promote seed germination by releasing dormancy (Nickell, 1982), mobilize nutrients (Kumar and Purohit, 1986), rupture pericarp by cotyledonary expansion and thereby improve germination (Bradbeer, 1988). Significant improvement in germination of $Q$. leucotrichophora seeds under $\mathrm{GA}_{3}(200 \mu \mathrm{M})$ treatment corresponds with similar reports in case of Q. rubra (Vogth, 1970) and Q.falcate (Bonner, 1976).

Although the beneficial effect of IAA has also been reported (Chatterjee, 1960), however, treatments with varying concentrations of IAA were found either ineffective or inhibitory in the present study. It may be due to the reason that IAA can stimulate transcription of 1aminocyclopropane-1-carboxylic acid (ACC) synthase. This enzyme facilitates a key step in ACC oxidase-mediated ethylene biosynthesis (Mayak et al., 1999). The IAA-derived ethylene is believed to participate in the disruption of the normal growth (i.e. germination and seedling growth) of the host plant.

Among nitrogenous compounds, use of Thiourea and $\mathrm{KNO}_{3}$ on oak seeds remained less effective. Thiourea has been reported by others to break seed dormancy and improve germination (Agarwal and Dadlani, 1995; Pandey et al., 2000). Likewise, Purohit et al. (2009) reported $\mathrm{KNO}_{3}$ treatments to be highly effective in improving seed germination of $Q$. glauca and Q. leucotrichophora. Present study, however, does not fall in full agreement with these reports. 


\section{Conclusions}

The study concludes the following: (i) larger size seeds of studied oaks respond better for germination, (ii) water soaking $(48 \mathrm{~h})$ is most effective treatment for enhancing germination, (iii) acid scarification also emerges as suitable pre-sowing treatment. While considering the cost effectiveness, water soaking seems to be the most potential treatment for being accepted by rural communities towards promotion of community forestry and non-government organization for nursery development to support large scale plantations in the region.

\section{Acknowledgements}

Authors are thankful to the Director, G. B. Pant National Institute of Himalayan Environment and Sustainable Development (GBPNIHESD), Kosi-Katarmal, Almora (Uttarakhand), India, for facilities and encouragement. Financial support from Department of Science and Technology (DST-INSPIRE, IF131069), India is gratefully acknowledged.

\section{References}

Agarwal PK, Dadlani M (1995). Techniques in Seed Science and Technology (II nd edition). South Asian Publishers Ltd, India.

Airi S, Rawal RS, Dhar U (2005). Presowing treatment effects on germination of Cornus capitata seeds. Seed Science and Technology 33:77-86.

Bhardwaj DR, Mishra VK, Shamet GS (1996). Rooting response of Quercus leucotrichophora Linn. cuttings to chemical treatments and physiochemical status. Journal of Tree Science 15:49-51.

Bhatt ID, Rawal RS, Dhar U (2000). Improvement in seed germination of Myrica esculenta Buch- Ham. Ex D. Don- a high value tree species of Kumaun Himalaya, India. Seed Science and Technology 28:597-605.

Bhuyan P, Khan ML, Shankar U (2000). Trade-off between dispersal efficiency and seedling fitness in Oroxylum indicum, a wind dispersed tropical tree. International Journal of Ecology and Environment Sciences 26:67-73.

Bonfil C (1998). The effect of seed size, cotyledon reserves, and herbivory on seedling survival and growth in Quercus mugosa and Q. Laurina (Fagaceae). American Journal of Botany 85:79-87.

Bonner FT (1976). Maturation of Shumard and white oak acorns. Forest Science 22:149-154.

Bradbeer JW (1988). Seed dormancy and germination. Blackie and son Ltd. Glasgow, UK, pp146.

Chatterjee SK (1960). Effect of pre-sowing treatments for Tung (Aleurites fordii). Science and Culture 26:130-131.

Hartmann HT, Kester DE (1989). Plant propagation: principles and practices. Prentice Hall, New Delhi.

Hendry GA, Grime JP (1993). Methods in comparative plant ecology. Chapman and Hall,London.
Khan ML, Shankar U (2001). Effect of seed weight, light regime and substratum micro-site on germination and seedling growth of Quercus semiserrata Roxb. Tropical Ecology 42:117-125.

Kumar A, Purohit SS (1986). Plant physiology: fundamental and applications. Agro Botanical Publisher, India.

Larsen HS (1963). Effects of soaking in water on acorn germination of four southern oak. Forest Science 9:236-241.

Mayak S, Tivosh T, Glick BR (1999). Effect of wild type and mutant plant growth-promoting rhizobacteria on the rooting of mung bean cutting. Journal of Plant Growth Regulators 18:49-53.

Murat Z, Zeynal T, Halil U (2010). The effects of different acid treatment and stratification duration on germination of Cercis siliquastrum seeds. Notulae Botanicae Horti Agrobotanici Cluj-Napoca 38:159-163.

NegiSS, Naithani HB (1995). Oaks of India, Nepal and Bhutan. Dehradun: International Book Distributors.

Nickell LG (1982). Plant growth regulator-agricultural uses. Springer-Verlag, Berlin-Heidelberg, pp 173.

Oldfield S, Eastwood A (2007). The red lists of Oaks. Fauna and Flora International, Cambridge, UK.

Pandey H, Nandi SK, Nadeem M, Palni LMS (2000). Chemical stimulation of seed germination in Aconitum heterophyllum Wall. and A. balfourii stapf: Important Himalayan species of medicinal value. Seed Science and Technology 28:39-48.

Purohit VK, Palni LMS, Nandi SK (2009). Effect of pre-germination treatments on seed physiology and germination of central Himalayan oaks. Physiology and Molecular Biology of Plants 15:319-326.

Purohit VK, Tamta S, Nandi SK, Rikhari HC, Palni LMS (2003). Does acorn weight influence germination and subsequent seedling growth of central Himalayan oaks? Journal of Tropical Forest Science 15:483-492.

Ren J, Tao L (2004). Effects of different pre-sowing seed treatments on germination of 10 Calligonum species. Forest Ecology and Management 195:291-300.

Saxena AK, Singh JS (1984). Tree population structure of certain Himalayan forest associations and implications concerning their future composition. Vegetation 58:61-69.

TamtaS, Purohit VK, Nandi SK, Palni LMS (2000). Chemical induction of root formation in Quercus leucotrichophora L. Stem cutting. Indian Journal of Forestry 23:135-138.

Thandani R, Ashton PMS (1995). Regeneration of Banj oak (Quercus leucotrichophora A. Camus) in the central Himalaya. Forest Ecology and Management 78:217-224.

Tilki F, Alptekin CU (2006). Germination and seedling growth of Quercus vulcanica: effects of stratification, desiccation, radical pruning and season of sowing. New Forests 32:243-251.

Tripathi RS, Khan ML (1990). Effects of seed weight and microsite characteristics on germination and seedling fitness in two species of Quercus in a subtropical wet hill forest. Oikos 57:289-296.

Vogth AR (1970). Effect of Gibberellic acid on germination and initial seedling growth of northern red oak. Forest Science 16:453-459. 